\title{
ANALISIS RISIKO PERENCANAAN INDUSTRI PENGOLAHAN IKAN DI PELABUHAN PERIKANAN SAMUDERA (PPS) KUTARAJA
}

\author{
Muhammad Arif ${ }^{1}$, Fis Purwangka ${ }^{2}$, Retno Muninggar ${ }^{2}$ \\ ${ }^{1}$ Program Studi Teknologi Perikanan Laut, \\ ${ }^{2}$ Departemen Pemanfaatan Sumberdaya Perikanan, \\ Fakultas Perikanan dan Ilmu Kelautan, IPB University \\ E-mail: mhmd.ariiff@gmail.com
}

\begin{abstract}
ABSTRAK
PER.08/MEN/2012 menyatakan bahwa pelabuhan tipe A harus memiliki industri pengolahan ikan dan industri penunjang lainnya. Keberadaan industri tersebut berdampak positif bagi masyarakat sekitar dan juga kepada nelayan, dimana hasil tangkapan nelayan selalu laku terjual dikarenakan adanya industri-industri yang membelinya. Hasil survei awal oleh peneliti didapatkan bahwa pihak pengelola pelabuhan sudah merencanakan pembangunan industri pengolahan ikan namun belum adanya kajian yang membahas terkait analisis risiko. Analisis risiko penting dilakukan untuk menghindari terjadinya kerugian berupa biaya, mutu dan waktu pada perencanaan industri. Dalam upaya untuk menghindari hal tersebut, maka tujuan penelitian ini yaitu menetapkan risiko prioritas dalam perencanaan industri pengolahan ikan di PPS Kutaraja. Metode yang digunakan yaitu House of Risk (HOR) untuk menentukan penyebab risiko yang menjadi prioritas untuk dilakukan tindakan mitigasi berdasarkan nilai Aggregate Risk Potential (ARP) teringgi. Hasil penelitian menunjukkan bahwa ada 11 penyebab risiko yang menjadi prioritas tertinggi untuk dilakukan mitigasi. Penyebab risiko tertinggi yaitu ketidakcukupan aliran kas (A13) dengan nilai ARP 423 dan nilai kumulatif ARP 11,22\%, sedangkan penyebab risiko pada prioritas terendah yaitu kekurangan sarana dan prasarana produksi (A2) dengan nilai ARP 144 nilai kumulatif ARP 76,93\%.
\end{abstract}

Kata kunci: House of Risk; Perencanaan Industri; Prioritas Risiko.

\section{RISK ANALYSIS OF FISH PROCESSING INDUSTRY PLANNING IN PELABUHAN PERIKANAN SAMUDERA (PPS) KUTARAJA}

\begin{abstract}
PER.08/MEN/2012 states that type A ports must have a fish processing industry and other supporting industries. The existence of the industry has a positive impact on the surrounding community and also for fishermen, where fishermen's catches are always sold because they are bought by the industry. The initial survey results by researcher is obtained that the port manager has planned the development of the fish processing industry but there are no studies that discuss risk analysis. Risk analysis is important to avoid losses in the form of cost, quality and time in industrial planning. In an effort to avoid this, the aim of this study is to establish priority risks in the planning of the fish processing industry in PPS Kutaraja. The method used is the House of Risk (HOR) to identify risk events, causes of risk and also determine the causes of risk that are priorities for mitigation actions based on the highest Aggregate Risk Potential (ARP) value. The results showed that there were 11 causes of risk which were the highest priority for mitigation. The highest cause of risk is inadequate cash flow (A13) with an ARP value of 423 and cumulative ARP value of $11,22 \%$, while the cause of risk at the lowest priority is the lack of production facilities and infrastructure (A2) with ARP value of 144 cumulative ARP value of 76,93\%.
\end{abstract}

Keywords: house of risk; Industrial planning; risk priority.

\section{PENDAHULUAN}

Provinsi Aceh merupakan salah satu kepulauan yang memiliki pelabuhan sentra perikanan terbesar (tipe A) yaitu Pelabuhan Perikanan Samudera (PPS) Kutaraja dengan karakteristik hasil tangkapan yang sangat beragam (Salmarika et al., 2019). Saat ini kawasan industri PPS Kutaraja hanya memiliki industri pengolahan ikan tuna frozen dan loin, namun terdapat beberapa industri pengolahan ikan lainnya yang berada di luar kawasan industri PPS Kutaraja. Terkait hasil tangkapan ikan, terdapat beberapa jenis ikan dominan yang berada di PPS Kutaraja diantaranya ikan tuna, ikan tongkol, ikan cakalang dan ikan layang (UPTD PPS Kutaraja, 2018). Beberapa jenis ikan dominan tersebut memberikan peluang untuk dijadikan bahan baku industri pengolahan ikan.

Hadirnya pelabuhan perikanan di suatu daerah harus mampu mendorong kegiatan ekonomi lainnya sehingga pelabuhan perikanan menjadi pusat kawasan pengembangan industri perikanan. Berdasarkan PER.08/MEN/2012 tentang Kepelabuhanan Perikanan, Pelabuhan Perikanan Samudera (PPS) sudah seharusnya memiliki industri pengolahan ikan dan industri penunjang lainnya. Keberadaan industri pengolahan ikan di PPS Kutaraja sangat penting, karena ikan-ikan yang didaratkan tidak hanya dapat dijual dalam bentuk segar tetapi juga dapat dijual dalam bentuk olahan yang memiliki nilai tambah.

Hasil survei awal yang dilakukan oleh peneliti didapatkan bahwa pihak pengelola pelabuhan sudah mulai merencanakan pembangunan industri pengolahan ikan di PPS Kutaraja, namun belum adanya kajian-kajian yang membahas terkait perencanaan industri pengolahan ikan. Salah satu kajian penting yang dilakukan dalam perencanaan industri adalah kajian tentang analisis risiko. 
Upaya untuk mengurangi dampak terjadinya risiko dari perencanaan industri pengolahan ikan salah satunya dengan cara melakukan identifikasi risiko yang bertujuan untuk menguraikan dan merinci jenis risiko yang mungkin terjadi pada aktivitas atau kegiatan perencanaan yang akan dilakukan, sehingga dapat dilakukan strategi mitigasi pada risiko yang muncul (Pertiwi et al., 2016). Tujuan penelitian ini yaitu mengidentifikasi dan menetapkan risiko prioritas dalam perencanaan industri pengolahan ikan di PPS Kutaraja.

\section{METODE}

Penelitian ini dilaksanakan pada bulan Oktober sampai bulan November 2019. Objek dalam penelitian ini adalah risiko perencanaan industri pengolahan ikan di Pelabuhan Perikanan Samudera (PPS) Kutaraja terkait 5 aspek risiko yaitu aspek risiko teknis, risiko pasar, risiko finansial, risiko manajemen serta risiko lingkungan dan masyarakat (Asmarantaka, 2014; Dharmika et al., 2015; Yulandari et al., 2015).

Metode pengumpulan data menggunakan metode wawancara dengan panduan kuesioner dan pengamatan langsung di lapangan. Teknik penentuan responden yang digunakan ada 2 cara yang pertama dengan purposive sampling dengan responden terdiri dari pihak Dinas Kelautan dan Perikanan (DKP) Provinsi Aceh sebanyak 2 orang serta pengelola PPS Kutaraja sebanyak 3 orang. Teknik pengambilan responden kedua dengan cara sensus dengan responden yaitu pemilik usaha pengolahan ikan yang berada di luar kawasan PPS Kutaraja (5 pemilik usaha pengolahan). Sedangkan analisis data yang digunakan dalam penelitian ini yaitu analisis House of Risk (HOR).

\section{House of Risk (HOR)}

Analisis House of Risk (HOR) merupakan suatu metode untuk manajemen risiko secara proaktif, dimana penyebab risiko yang teridentifikasi dapat dikelola dengan cara memberikan urutan berdasarkan besarnya dampak yang mungkin ditimbulkan (Ummi et al., 2017; Amran \& Junaedi, 2019). Analisis HOR terbagi menjadi 2 tahap yaitu HOR 1 digunakan untuk menentukan penyebab risiko mana yang diprioritaskan untuk dilakukan tindakan pencegahan dan HOR 2 digunakan untuk memberikan prioritas tindakan pencegahan dengan mempertimbangkan sumber daya biaya yang efektif (Sibuea \& Saragi, 2019).

Penelitian ini hanya membahas sebatas risiko apa saja yang menjadi prioritas dalam perencanaan industri pengolahan ikan di PPS Kutaraja sehingga analisis HOR yang digunakan hanya analisis HOR 1 dan dibantu dengan menggunakan hukum pareto 80/20. Adapun langkah-langkah dalam HOR 1 yaitu: 1) mengidentifikasi kejadian risiko (risk event, Ei) dan melakukan pengukuran tingkat dampak keparahan (severity, $\mathrm{Si}$ ) dengan menggunakan skala 1 hingga 5 (Tabel 1), 2) mengidentifikasi penyebab risiko (risk agent, $\mathrm{Aj}$ ) dan melakukan pengukuran tingkat tingkat kemunculan (occurrence, Oi) dengan menggunakan skala 1 hingga 5 (Tabel 1), 3) pengukuran nilai korelasi (Rij) antara suatu kejadian risiko dengan penyebab risiko, yang mana apabila suatu penyebab risiko menyebabkan timbulnya kejadian risiko maka dikatakan terdapat korelasi. Pengukuran korelasi menggunakan nilai 0,1,3,9 (Maharani 2018), dimana skala 0 jika tidak ada korelasi, skala 1 jika korelasi rendah, skala 3 jika korelasi sedang dan skala 9 jika korelasi tinggi, 4) menghitung nilai Aggregate Risk Potential dengan menggunakan rumus $\mathrm{ARP}=\mathrm{Oi} \sum \mathrm{Si}$. Rij, 5) melakukan penyusunan peringkat penyebab risiko sesuai dengan nilai ARP terbesar hingga nilai ARP yang terkecil.

Tabel 1 Penilaian tingkat keparahan dan tingkat kemunculan.

\begin{tabular}{|c|c|c|c|c|}
\hline & $\begin{array}{c}\text { Tingkat } \\
\text { Keparahan }\end{array}$ & Diskripsi & $\begin{array}{c}\text { Tingkat } \\
\text { Kemunculan }\end{array}$ & Diskripsi \\
\hline 5 & Sangat Tinggi & $\begin{array}{l}\text { Kerusakan atau kerugian materi } \\
\text { mencapai lebih dari } 1 \text { milyar } \\
\text { rupiah }\end{array}$ & Sering Terjadi & $\begin{array}{l}\text { Kejadian sudah } \\
\text { diperkirakan terjadi }\end{array}$ \\
\hline 4 & Besar & $\begin{array}{l}\text { Kerusakan atau kerugian materi } \\
\text { antara } 100 \text { juta - } 1 \text { milyar } \\
\text { rupiah }\end{array}$ & $\begin{array}{l}\text { Pernah Terjadi } \\
\text { Sebelumnya }\end{array}$ & $\begin{array}{l}\text { Kejadian ini mungkin } \\
\text { terjadi }\end{array}$ \\
\hline 3 & Menengah & $\begin{array}{l}\text { Kerugian materi antara } 50 \text { juta } \\
-100 \text { juta rupiah }\end{array}$ & Dapat Terjadi & $\begin{array}{l}\text { Kejadian ini mungkin } \\
\text { terjadi di suatu waktu }\end{array}$ \\
\hline 2 & Kecil & $\begin{array}{l}\text { Kerugian materi antara } 10 \text { juta } \\
-50 \text { juta rupiah }\end{array}$ & Jarang & $\begin{array}{l}\text { Bisa terjadi tetapi tidak } \\
\text { diharapkan }\end{array}$ \\
\hline 1 & Sangat Rendah & $\begin{array}{l}\text { Kerugian materi antara } 0-10 \\
\text { juta rupiah }\end{array}$ & Sangat Jarang & $\begin{array}{l}\text { Terjadi hanya dalam } \\
\text { situasi tertentu }\end{array}$ \\
\hline
\end{tabular}

(Sumber : Maharani, 2018)

\section{HASIL DAN PEMBAHASAN}

\section{Analisis Identifikasi Risiko dan Sumber Risiko}

Identifikasi risiko awal dilakukan pada penelitian pendahuluan dan studi pustaka terkait risiko-risiko apa saja yang muncul atau mungkin terjadi dari perencanaan industri pengolahan ikan. Hasil identifikasi risiko yang dilakukan terdapat 19 tejadian risiko (risk event) yang muncul dan mungkin terjadi pada perencanaan industri pengolahan ikan. Daftar kejadian risiko dan penilaian tingkat keparahan (severity) risiko tersebut dapat dilihat pada Tabel 2. 
Tabel 2 menunjukan bahwa terdapat 2 risiko yang memiliki nilai tingkat keparahan sangat tinggi dengan nilai skala 5 yaitu risiko bahan baku ikan tidak tersedia atau tidak cukup (E6) dan risiko ketersediaan keuangan selama pelaksanaan pembangunan (E10). Risiko tersebut memiliki nilai yang tinggi dikarenakan berhubungan langsung dengan terhentinya proses pengoperasian industri. Sedangkan hanya terdapat satu kejadian yang memiliki nilai dampak keparahan terendah dengan skala 2 yang berarti risiko tersebut kecil yaitu risiko biaya produksi yang tinggi (E9). Langkah berikutnya yaitu melakukan identifikasi penyebab risiko (risk agent) dan diberikan penilaian tingkat kemunculan (occurrence) penyebab risiko tersebut. Hasil identifikasi risiko yang dilakukan terdapat 24 kejadian risiko yang muncul dan mungkin terjadi pada perencanaan industri pengolahan ikan. Penyebab risiko yang telah teridentifikasi dan penilaian tingkat kemunculan risiko tersebut dapat dilihat pada Tabel 3 .

Tabel 2 Daftar kejadian risiko dan penilaian tingkat keparahan.

\begin{tabular}{clc}
\hline Kode & \multicolumn{1}{c}{ Kejadian risiko } & $\begin{array}{c}\text { Tingkat } \\
\text { keparahan }\end{array}$ \\
\hline E1 & Target produksi tidak tercapai & 4 \\
E2 & Terlambatnyaa proses produksi ikan yang diolah & 4 \\
E3 & Cara penanganan bahan baku yang tidak baik & 4 \\
E4 & Perencanaan yang kurang baik & 4 \\
E5 & Perizinan yang sulit & 3 \\
E6 & Bahan baku ikan tidak tersedia atau tidak cukup & 5 \\
E7 & Harga bahan baku tidak stabil & 4 \\
E8 & Kerusakan produk selama perjalanan & 3 \\
E9 & Biaya produksi yang tinggi & 2 \\
E10 & Ketersediaan keuangan selama pelaksaan produksi & 5 \\
E11 & Keterlambatan proses pembayaran pekerja & 4 \\
E12 & Target produksi yang tak tercapai & 3 \\
E13 & Produk yang dihasilkan tidak sesuai standar & 4 \\
E14 & Tatalaksana perencanaan perindustrian yang tidak sesuai & 4 \\
E15 & Tidak adanya prosedur operasional setiap pekerjaan & 3 \\
E16 & Pengaruh cuaca pada aktivitas pengoperasian & 3 \\
E17 & Pengaruh keamanan lingkungan terhadap pengoperasian & 4 \\
E18 & Polusi dan kontaminasi akibat pengoperasian & 4 \\
E19 & Tidak adanya komunikasi antara pengusaha dengan masyarakat & 3 \\
\hline
\end{tabular}

(Sumber : Data Primer)

Tabel 3 Daftar penyebab risiko dan penilaian tingkat kemunculan.

\begin{tabular}{clc}
\hline Kode & \multicolumn{1}{c}{ Penyebab risiko } & Tingkat kemunculan \\
\hline A1 & Kerusakan alat produksi & 2 \\
A2 & Kekurangan sarana dan prasarana produksi & 3 \\
A3 & Kualitas tidak sesuai dengan standar mutu & 3 \\
A4 & Kesalahan estimasi biaya dan waktu & 3 \\
A5 & Studi kelayakan yang buruk & 4 \\
A6 & Ketidakpastian hukum & 2 \\
A7 & Faktor musiman & 2 \\
A8 & Harga pembelian ikan melabung tinggi & 3 \\
A9 & Produk tidak laku dijual & 2 \\
A10 & Alat transportasi yang tidak aman dari faktor lingkungan & 2 \\
A11 & Terjadinya inflasi & 1 \\
A12 & Ketidakstabilan pasar & 4 \\
A13 & Ketidakcukupan aliran kas & 3 \\
A14 & Pekerja mengundurkan diri & 2 \\
A15 & Kurangnya ketersediaan tenaga kerja yang berkompeten & 2 \\
A16 & Kualitas produk tidak baik & 2 \\
A17 & Kesalahan prosedur pengerjaan & 3 \\
A18 & Perencanaan yang kurang matang & 2 \\
A19 & Manajemen perindustrian yang tidak baik & 2 \\
A20 & Proses pengoperasian terganggu atau terhenti & 2 \\
A21 & Pengelolaan limbah padat dan cair yang dilakukan tidak benar & 2 \\
A22 & Lalu lintas semakin meningkat sehingga terjadinya kebisingan, debu, dan & 1 \\
A23 & perasaan tidak nyaman & 2 \\
A24 & Terjadinya demo & 1 \\
\hline
\end{tabular}

(Sumber : Data Primer) 
Tabel 3 menunjukan penilaian tingkat kemunculan dari penyebab risiko (risk agent) pada perencanaan industri pengolahan. Hasil penelitian terdapat 2 risiko yang memiliki nilai tingkat kemunculan dengan nilai skala 4 yang berarti risiko tersebut kemungkinan pernah terjadi sebelumnya yaitu risiko studi kelayakan yang buruk (A5) dan risiko ketidakstabilan pasar (A12). Sedangkan terdapat 3 risiko yang memiliki nilai tingkat kemunculan dengan skala 1 yang berarti risiko tersebut sangat jarang terjadi yaitu risiko terjadinya inflasi (A11), risiko lalu lintas semakin meningkat sehingga terjadinya kebisingan, debu, dan perasaan tidak nyaman (A22), serta risiko terjadinya demo (A24). Lalu sisanya merupakan penyebab risiko yang kemungkinan dapat terjadi, jarang terjadi dan sangat jarang terjadi.

\section{Pemetaan Analisis House of Risk (HOR)}

Pemetaan dilakukan dengan memasukkan hasil penilaian tingkat keparahan dari kejadian risiko dan penilaian tingkat kemunculan dari penyebab risiko yang selanjutnya dilakukan pengukuran nilai korelasi antara kedua risiko tersebut. Pengukuran nilai korelasi menggunakan skala $0,1,3,9$, dimana skala 0 jika tidak ada korelasi, skala 1 jika korelasi rendah, skala 3 jika korelasi sedang dan skala 9 jika korelasi tinggi (Pedekawati et al., 2017). Setelah diidentifikasi kejadian risiko dan penyebab risiko yang terjadi serta sudah diberikan penilaian, maka data-data tersebut dimasukkan ke dalam tabel HOR 1 (Tabel 4) untuk mengetahui nilai ARP (Amelia et al., 2017).

Tabel 4 menunjukan tahapan dalam HOR 1 yang digunakan untuk menentukan penyebab risiko yang harus diberikan prioritas untuk tindakan pencegahan berdasarkan nilai ARP terbesar hingga nilai yang terkecil.

Tabel 4 Hasil analisis HOR 1.

\begin{tabular}{|c|c|c|c|c|c|c|c|c|c|c|c|c|c|c|c|c|c|c|c|c|c|c|c|c|c|}
\hline \multirow{2}{*}{ Risik event (Ei) } & \multicolumn{24}{|c|}{ Risk agents (Aj) } & \multirow{2}{*}{$\begin{array}{c}\text { Severity of risk } \\
\text { event } i \text { (Si) }\end{array}$} \\
\hline & $\mathrm{A} 1$ & $\mathrm{~A} 2$ & A3 & $\mathrm{A} 4$ & A5 & A6 & A7 & A8 & A9 & $\mathrm{A} 10$ & A11 & $\mathrm{A} 12$ & A13 & A14 & $\mathrm{A} 15$ & A16 & A17 & A18 & A19 & $\mathrm{A} 20$ & A21 & A22 & $\mathrm{A} 23$ & $\overline{\mathrm{A} 24}$ & \\
\hline E1 & 9 & 3 & & 3 & & & 1 & & & & & 3 & 3 & & & & & 3 & & 9 & & & & & 4 \\
\hline E2 & 9 & 3 & & 3 & & & & & & & & & & & & & & & 1 & 9 & & & & & 4 \\
\hline E3 & & & 9 & & & & & & & & & & & & & 1 & & & & & & & & & 4 \\
\hline E4 & & & 3 & 3 & 9 & & & & & & & & & & & & & 3 & & & 9 & & 9 & & 4 \\
\hline E5 & & & & 9 & & 3 & & & & & & & & & & & & & & & & & & & 3 \\
\hline E6 & & & & & 3 & & 9 & 1 & & & & 3 & & & & & & & & & & & & & 5 \\
\hline E7 & & & & & & & 3 & 9 & & & & & 9 & & & & & & & & & & & & 4 \\
\hline E8 & & & & & & & 1 & & 3 & 3 & & & & & & & & & & & & & & & 3 \\
\hline E9 & & & & & 1 & & 3 & 9 & & & 3 & & & & & & & & & & & & & & 2 \\
\hline E10 & 1 & 3 & & & & & & & & & & 9 & 9 & 3 & & & & & & & & & & & 5 \\
\hline E11 & & & & & & & & & & & & & 9 & 9 & & & & & & & & & & 3 & 4 \\
\hline E12 & 9 & 3 & & 3 & & & & & & & & 3 & & 3 & 9 & & & & & 3 & & & & & 3 \\
\hline E13 & & & 9 & & & & & & & 3 & & 3 & 3 & & & 9 & 3 & & & & & & & & 4 \\
\hline E14 & & & 3 & 3 & 9 & & & & & & & & & & & & 3 & 3 & 1 & & 3 & & & & 4 \\
\hline E15 & & & & & & & & & & & & & & & & & 3 & 3 & 9 & & & & 3 & & 3 \\
\hline E16 & & & & 3 & & & 1 & & & & & & & & & & & & & 9 & & & & & 3 \\
\hline E17 & & & 9 & & & & & & & & & & & & & & & & & & 9 & 9 & & 3 & 4 \\
\hline E18 & & & & & & & & & & & & & & & & & & & & & 3 & 9 & 9 & 9 & 4 \\
\hline E19 & & & & & & & & & & & & & & & & & & & & & & 3 & & 9 & 3 \\
\hline Occurrence of agent $j$ & 2 & 3 & 3 & 3 & 4 & 2 & 2 & 3 & 2 & 2 & 1 & 4 & 3 & 2 & 2 & 2 & 3 & 2 & 2 & 2 & 2 & 1 & 2 & 1 & \\
\hline Aggregate risk potential $j$ & 208 & 144 & 396 & 279 & 356 & 18 & 86 & 177 & 12 & 42 & 6 & 336 & 423 & 120 & 54 & 80 & 99 & 90 & 88 & 228 & 192 & 81 & 162 & 87 & \\
\hline Priority rank of agent $j$ & 7 & 11 & 2 & 5 & 3 & 22 & 17 & 9 & 23 & 21 & 24 & 4 & 1 & 12 & 20 & 19 & 13 & 14 & 16 & 6 & 8 & 18 & 10 & 16 & \\
\hline
\end{tabular}

(Sumber : Data Olahan)

\section{Penentuan risiko prioritas}

Penentuan risiko prioritas menggunakan hukum pareto 80/20, konsep ini dapat dijelaskan bahwa $80 \%$ penyebab risiko (risk agent) dengan nilai ARP tertinggi menjadi risiko prioritas untuk dilakukan penanganan (Ummi et al., 2017), diharapkan dengan memfokuskan kepada $80 \%$ risiko yang krusial maka dampak risiko sebesar $20 \%$ dapat teratasi. Dalam penanganan risiko, tidak semua penyebab risiko mendapatkan penanganan. Hal ini disebabkan oleh beberapa faktor seperti dari segi biaya yang dikeluarkan dalam proses penanganan terlalu banyak dan tingkat dampak yang ditimbulkan dianggap terlalu kecil (Maharani, 2018). Oleh karena itu, penyebab risiko yang akan ditangani adalah yang dianggap prioritas dengan menggunakan hukum pareto dengan konsep 80/20. Penentuan kategori penyebab risiko prioritas dapat dilihat pada Gambar 1 dan Tabel 5.

Gambar 1 memperlihatkan bahwa hanya ada 11 penyebab risiko yang termasuk ke dalam kategori risiko tinggi dengan nilai kumulatif ARP sebesar $80 \%$. Adapun penyebab risiko yang termasuk ke dalam kategori tinggi yaitu A13, A3, A5, A12, A4, A20, A1, A21, A8, A23, A2 dan sisanya termasuk ke dalam kategori rendah, dimana penyebab risiko tertinggilah yang menjadi prioritas untuk dilakukan tindakan pencegahan. Penentuan kategori penyebab risiko prioritas secara lebih jelas dapat dilihat pada Tabel 5. 


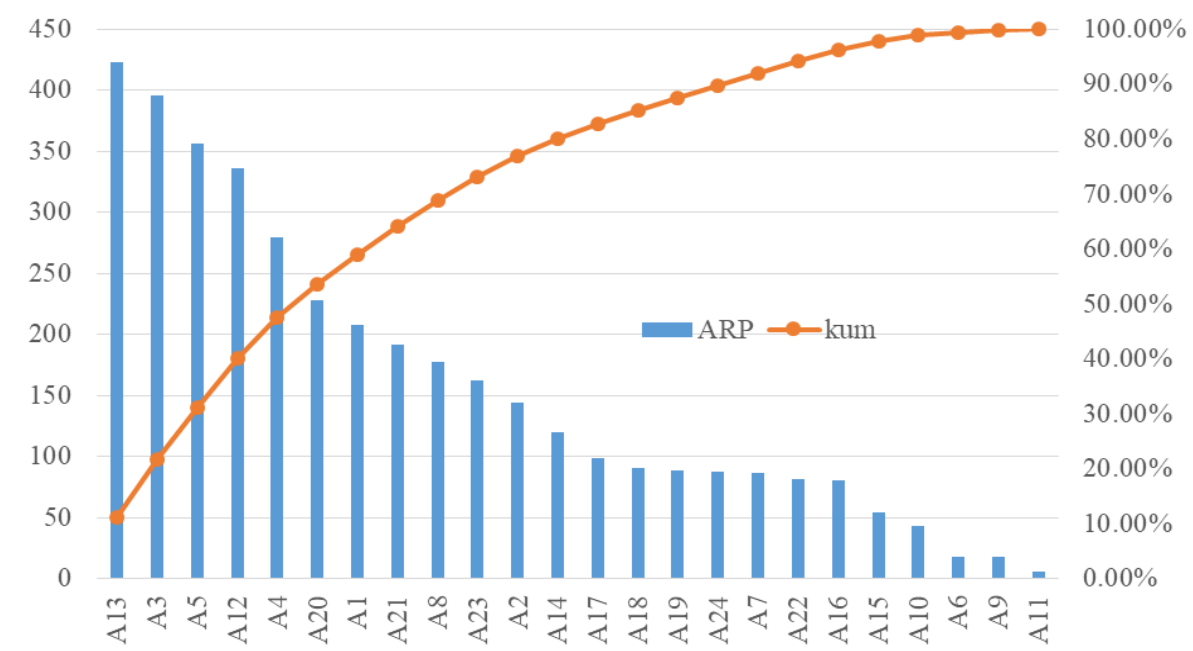

Gambar 1 Diagram pareto.

.Tabel 5 Prioritas penyebab risiko.

\begin{tabular}{|c|c|c|c|c|c|}
\hline Penyebab risiko & Peringkat & ARP & $\%$ ARP & $\%$ Kumulatif ARP & Kategori \\
\hline A13 & 1 & 423 & $11,22 \%$ & $11,22 \%$ & \multirow{11}{*}{ Prioritas } \\
\hline A3 & 2 & 396 & $10,50 \%$ & $21,72 \%$ & \\
\hline A5 & 3 & 356 & $9,44 \%$ & $31,16 \%$ & \\
\hline A12 & 4 & 336 & $8,91 \%$ & $40,07 \%$ & \\
\hline A4 & 5 & 279 & $7,40 \%$ & $47,47 \%$ & \\
\hline A20 & 6 & 228 & $6,05 \%$ & $53,51 \%$ & \\
\hline $\mathrm{A} 1$ & 7 & 208 & $5,52 \%$ & $59,03 \%$ & \\
\hline A21 & 8 & 192 & $5,09 \%$ & $64,12 \%$ & \\
\hline A8 & 9 & 177 & $4,69 \%$ & $68,81 \%$ & \\
\hline A23 & 10 & 162 & $4,30 \%$ & $73,11 \%$ & \\
\hline $\mathrm{A} 2$ & 11 & 144 & $3,82 \%$ & $76,93 \%$ & \\
\hline A14 & 12 & 120 & $3,18 \%$ & $80,11 \%$ & \multirow{13}{*}{$\begin{array}{c}\text { Non } \\
\text { prioritas }\end{array}$} \\
\hline A17 & 13 & 99 & $2,63 \%$ & $82,74 \%$ & \\
\hline A18 & 14 & 90 & $2,39 \%$ & $85,12 \%$ & \\
\hline A19 & 15 & 88 & $2,33 \%$ & $87,46 \%$ & \\
\hline A24 & 16 & 87 & $2,31 \%$ & $89,76 \%$ & \\
\hline A7 & 17 & 86 & $2,28 \%$ & $92,04 \%$ & \\
\hline A22 & 18 & 81 & $2,15 \%$ & $94,19 \%$ & \\
\hline A16 & 19 & 80 & $2,12 \%$ & $96,31 \%$ & \\
\hline A15 & 20 & 54 & $1,43 \%$ & $97,75 \%$ & \\
\hline A10 & 21 & 43 & $1,14 \%$ & $98,89 \%$ & \\
\hline A6 & 22 & 18 & $0,48 \%$ & $99,36 \%$ & \\
\hline A9 & 23 & 18 & $0,48 \%$ & $99,84 \%$ & \\
\hline A11 & 24 & 6 & $0,16 \%$ & $100,00 \%$ & \\
\hline Total & & 3771 & $100,00 \%$ & & \\
\hline
\end{tabular}

(Sumber : Data Olahan)

Tabel 5 di atas dapat dilihat bahwa dari 11 penyebab risiko yang menjadi prioritas tertinggi terdapat pada kode A13 yaitu ketidakcukupan aliran kas dengan nilai ARP 423 dan nilai kumulatif 11,22\%. Hasil wawancara didapatkan bahwa pada umumnya industri skala kecil yang berada di luar PPS Kutaraja tidak ada pembukuan yang jelas, sehingga bisa saja modal usaha dengan uang pribadi dapat tercampur yang mengakibatkan ketidakcukupan aliran kas. Selain itu, ketidakcukupan aliran kas juga dapat menyebabkan terhambatnya dalam penyediaan bahan baku, pembayaran karyawan yang tidak sesuai, berkurangnya tenaga kerja hingga yang paling parah yaitu terhentinya pengoperasian industri akibat kebangkrutan (Subani, 2015). Sedangkan penyebab risiko dengan prioritas terendah terdapat pada kode A2 yaitu kekurangan sarana dan prasarana produksi dengan nilai ARP 144 dan nilai kumulatif $76,93 \%$. Hasil wawancara didapatkan bahwa kendala utama dari proses industri yaitu kekurangan alat produksi, sehingga terhambatnya proses produksi ikan yang diolah. Sarana dan prasarana yang dimaksud antara lain yaitu peralatan yang memadai, akses jalan, penyediaan air bersih dan pengolahan limbah terpadu, jaringan listrik, jaringan telekomunikasi dan jasa ekspedisi (Hariz et al., 2018). Penyebab risiko ini menjadi prioritas karena sarana 
dan prasarana yang tidak tersedia akan menghambat proses perindustrian.

\section{SIMPULAN}

Berdasarkan hasil penelitian yang telah dilakukan di PPS Kutaraja terkait perencanaan industri pengolahan ikan menggunakan metode HOR, maka dapat disimpulkan bahwa terdapat 19 kejadian risiko (risk event) dan terdapat 24 penyebab risiko (risk agent) yang teridentifikasi berpeluang timbul pada perencanaan industri pengolahan ikan. Perhitungan dengan menggunakan diagram pareto $80 / 20$ diperoleh 11 penyebab risiko yang menjadi prioritas untuk segera dimitigasi berdasarkan nilai ARP tertinggi yaitu ketidakcukupan aliran kas, kualitas tidak sesuai dengan standar mutu, studi kelayakan yang buruk, ketidakstabilan pasar, kesalahan estimasi biaya dan waktu, proses pengoperasian terganggu atau terhenti, kerusakan alat produksi, pengelolaan limbah padat dan cair yang dilakukan tidak benar, polusi dan kontaminasi akibat pengoperasian, kekurangan sarana dan prasarana produksi dan penurunan kualitas udara akibat pengoperasian.

\section{SARAN}

Saran untuk penelitian selanjutnya yaitu perlu dilakukan kajian lengkap mengenai strategi mitigasi berdasarkan risiko prioritas yang telah direkomendasikan.

\section{DAFTAR PUSTAKA}

Amelia P, Vanany I \& Indarso. (2017). Analisis Risiko Operasional pada Divisi Kapal Perang PT. PAL Indonesia dengan Metode House of Risk. Jurnal Sistem Informasi Indonesia, 1, (2), 1-11.

Amran TG \& Junaedi M. (2019). Model Perancangan Percepatan Pemasangan Ketel Uap Steam 2500 $\mathrm{kg} / \mathrm{h}$ Melihat dari Sisi Resiko dengan House Of Risk (HOR) Project PT. X. Seminar Nasional Pakar ke 2 (pp 1.66.1-1.66.7). Jakarta: Fakultas Teknologi Industri, Universitas Trisakti.

Asmarantaka NS. (2014). Analisis Risiko yang Berpengaruh Terhadap Kinerja Proyek pada Pembangunan Hotel Batiqa Palembang. Jurnal Teknik Dipil dan Lingkungan, 2, (3), 483-491.

Dharmika KY, Dharmayanti GAPC \& Purbawijaya IBN. 2015. Manajemen Risiko pada Pembangunan Pengembangan Hotel yang Sedang Beroperasi (Studi Kasus pada Pembangunan Extension Villa Hotel Alila Ubud). Jurnal Spektran, 3, (2), 47-56.
Hariz AR, Purwanto \& Suherman. (2018). Pengembangan Kawasan Industri Ramah Lingkungan Sebagai Upaya untuk Menjaga Keseimbangan Ekosistem (Studi Kasus di Taman Industri BSB Semarang). Journal of Biology and Applied Biology, 1, (1), 58-65.

[KKP] Kementerian Kelautan dan Perikanan. (2012). Keputusan Menteri Kelautan dan Perikanan Republik Indonesia Nomor PER.08/MEN/ 2012 tentang Kepelabuhanan Perikanan. Jakarta: KKP.

Maharani AR. (2018). Perancangan Manajemen Risiko Operasional di PT.X dengan Menggunakan Metode House of Risk. Tesis. Institut Teknologi Sepuluh November.

Pedekawati C, Karyani T \& Sulistyowati L. (2017). Implementasi House of Risk (HOR) petani dalam agribisnis mangga gedong gincu. Jurnal Agribisnis Terpadu, 10, (1), 97-112.

Pertiwi IGAIM, Kristinayanti W \& Aryawan IGMO. (2016). Manajemen Risiko Proyek Pembangunan Underpass Gatot Subroto Denpasar. Jurnal Akuntansi, Ekonomi dan Manajemen Bisnis, 1, (4), 1-6.

Salmarika, Taurusman AA \& Wisudo SH. (2018). Status Pengelolaan Sumber Daya Ikan Tongkol di Perairan Samudera Hindia Berbasis Pendaratan Pukat Cincin di Pelabuhan Perikanan Samudera Lampulo, Aceh: Suatu Pendekatan Ekosistem. Jurnal Penelitian Perikanan Indonesia, 4, (24), 263-272.

Sibuea ME \& Saragi HS. (2019). Analisis Risiko Keterlambatan Material dan Komponen pada Proyek Pembangunan Kapal dengan Metode House of Risk (HOR) Studi Kasus: Pembangunan Kapal Ro-Ro 300 GT Danau Toba. Jurnal Sistem Teknik Industri, 2, (21), 28-42.

Subani. (2015). Analisis Arus Kas untuk Mengukur Kinerja Keuangan (Studi pada KUD Sido Makmur Lumajang). Jurnal Wiga, 1, (5), 5867.

Ummi N, Gunawan A \& Ridwan M. (2017). Identifikasi Risiko Pembuatan Kue Gipang Sebagai Makanan Tradisional Khas Banten dengan Metode House of Risk (HOR). Journal Industrial Services, 3, (1), 342-350.

[UPTD PPS Kutaraja] Unit Pelaksana Teknis Daerah Pelabuhan Perikanan Samudera Kutaraja. (2018). Statistik Perikanan Tangkap. Kutaraja: UPTD PPS Kutaraja.

Yulandari L, Tjahjono A \& Riniwati H. 2015. Perencanaan Pengembangan Bisnis Pengolahan Ikan pada Rumah Makan Mina Sari Tlogomas, Malang, Jawa Timur. Jurnal Ecsofim, 1, (3), 27-38. 